\title{
STRUCTURE OF THE INCOMPATIBILITY GENE
}

\section{TYPES OF MUTATIONS IN PRUNUS AVIUM L.}

\author{
D. LEWIS and LESLIE K. CROWE \\ John Innes Horticultural institution. Hertford, Herts.
}

Received 24.xi.53

\section{INTRODUCTION}

THERE have been two main objects in the work on mutation of the incompatibility gene in Prunus:-(I) to investigate the types of spontaneous and X-ray induced mutations, and (2) to produce selffertile seedlings and from these to breed good self-fertile varieties of fruits.

Previous reports on mutations of the incompatibility gene have been mainly on Enothera organensis. But quantitative data in Prunus avium on the amount of seed produced after incompatible pollination with and without X-ray treatment, and calculated mutation rates based on all types of mutation have already been published (Lewis, 1948, 1949). Five years after the pollinations were made the seedlings flowered and have now been tested for their $\mathbf{S}$ genotypes.

The present account describes the types of mutations obtained spontaneously and after X-ray treatment. The results, some of which have been briefly reported (Lewis and Crowe, I953), confirm the general conclusions derived from Enothera. In detail, however, the situation is slightly different and has in consequence produced new information about such controversial issues as revertible mutations.

\section{MATERIAL AND METHODS}

The technique for $\mathrm{X}$-irradiation has been described elsewhere (Lewis, 1949).

The seedling trees to be tested and the horticultural varieties of known $\mathbf{S}$ genotype used as testers were grown in large pots and brought into an insect-proof greenhouse just before flowering in March. Flowers on trees which were self-fertile or of unknown genotype were emasculated before cross pollination. The degree of compatibility of a pollination was obtained from counts of fruits set at two periods after pollination and counts of seeds produced. The two fruit counts were made because in some pollinations there was a considerable stimulus to fruit swelling which was due to compatible pollen-tube growth, but the majority of zygotes failed to develop owing to zygotic lethals.

The routine method of testing a seedling was to self-pollinate and to cross with its parents in both directions. With critical crosses, the tests were repeated in a second year. The different results and 
their interpretations based on these tests are given in table I. Some of these results, Nos. 2, 3 and 4 are decisive and have only one explanation, but Nos. I, 5 and 6 each have two alternative explanations which cannot be distinguished without further breeding tests, and these are impracticable in Prunus owing to the long period of maturity. Result No. I includes homozygotes with the mutated allele having lost its pollen activity and heterozygotes with the mutated allele having lost both pollen and style activities. Result No. 5 is given by homozygotes only. In all of them a pollen mutant has reverted to a normal

TABLE I

Routine method of testing unknown seedlings for the $\mathbf{S}$ alleles (prefix ' $=$ lcss of pollen activity, $\mathrm{o}=$ loss of stylar activity)

\begin{tabular}{|c|c|c|c|c|c|c|}
\hline \multirow{2}{*}{ Pollination } & \multicolumn{6}{|c|}{ Different results obtained } \\
\hline & I & 2 & 3 & 4 & 5 & 6 \\
\hline $\begin{array}{l}\text { Seedling selfed } \\
\text { Parent }\left(\mathrm{S}_{1.2)} \text { as } q \text { : }\right. \\
\text { Seedling as } q\end{array}$ & $\begin{array}{l}+ \\
+ \\
+\end{array}$ & $\begin{array}{l}+ \\
+ \\
-\end{array}$ & $\frac{+}{+}$ & $\bar{z}$ & $\bar{z}$ & $\vec{t}$ \\
\hline $\begin{array}{l}\text { Possible genotype of } \\
\text { seedling }\end{array}$ & $\begin{array}{l}S_{2.2^{\prime}} \\
S_{1.1^{\prime}} \\
S_{1.2^{0}} \\
S_{I^{0} .2}\end{array}$ & $\begin{array}{c}\mathrm{S}_{1.2^{\prime}} \\
\mathrm{S}_{1^{\prime} \cdot 2} \\
\quad \ldots \\
\ldots\end{array}$ & $\begin{array}{c}S_{1.2^{0}} \\
S_{I^{0} .2} \\
\quad \ldots \\
\ldots\end{array}$ & $\begin{array}{c}S_{1.2} \\
\ldots \\
\ldots \\
\ldots\end{array}$ & $\begin{array}{l}S_{1.1} \\
S_{2.2} \\
S_{1}{ }^{0} .1 \\
S_{2}{ }^{0} .2\end{array}$ & $\begin{array}{c}\mathbf{S}_{1} . x \\
\mathbf{S}_{x .2} \\
\ldots \\
\ldots\end{array}$ \\
\hline Type of mutation & $\begin{array}{c}\text { Loss of } \\
\text { pollen or } \\
\text { both } \\
\text { parts }\end{array}$ & $\begin{array}{c}\text { Loss of } \\
\text { pollen } \\
\text { part }\end{array}$ & $\begin{array}{l}\text { Loss of } \\
\text { stylar } \\
\text { part }\end{array}$ & & $\begin{array}{l}\text { ible } \\
\text { ins }\end{array}$ & $\begin{array}{l}\text { New } \mathbf{S} \\
\text { allele or } \\
\text { contam- } \\
\text { ination }\end{array}$ \\
\hline
\end{tabular}

allele. Some types may in addition have lost their stylar activity but again only further tests in the next generation can distinguish between the mutations affecting I or 2 parts of the $S$ gene. In result 6 the possibility of a new active allele can only be distinguished from contamination if it is possible to test with all combinations of alleles which are present in the material, including both experimental and neighbouring sources of contamination. With Prunus this is an impossible task because only part of the possible sources of contamination are known genetically.

The 6 different classes will be described using the results of a typical case as illustration.

\section{RESULTS}

Type I (Table I)

This type of mutant is self-fertile and compatible both ways with the parent. The behaviour of Seedling I 4 I I $/ 46$ is typical of the group. This plant was obtained from self-pollinating an $\mathbf{S}_{3.6}$ tree without 
X-radiation. Self-pollination of the seedling produced 32 fruits from I54 flowers (2I per cent.), when crossed as a male on to the parent I5 fruits were produced from I io flowers (I4 per cent.), and the reciprocal cross gave 27 fruits from 54 flowers ( 50 per cent.). Thus all the pollinations are fully compatible, since compatible crosses in Prunus avium give a set of fruit ranging from 4 to 60 per cent., whereas incompatible crosses give less than 0.3 per cent. ( $c f$. Crane and Brown, 1937).

This type of result has two alternative interpretations-( $\mathrm{I})$ that in the mutant allele the pollen activity alone has been changed or (2) that both the stylar and pollen activity have been changed.

\section{Type 2}

Seedling $3 / 45$ was obtained from intercrossing two varieties of the incompatibility group III $\left(\mathbf{S}_{3.4}\right)$, Emperor Francis $\times$ Bigarreau Napoleon (X-rayed). Self-pollination of the seedling produced 40 fruits from 200 flowers (20 per cent.). When it was crossed as a male on to the parent I 72 fruits were produced from 257 flowers (67 per cent.), while the reciprocal cross gave no fruits from 60 flowers. The failure to set fruit when pollinated with the parent shows that the seedling was a heterozygote and that the stylar activity of the mutated allele is unaltered. The self-fertility and compatibility as a male on to the parent proves that the mutated allele has lost its original pollen activity. This type of mutation is identical with the self-fertile mutants produced in CEnothera organensis (Lewis, I95 I) and is a confirmation of the bipartite structure of the incompatibility gene in another species.

\section{Type 3}

This type of mutant is one of particular interest because it has not been found before. Seedling $6 x$ was obtained from Turkey Heart (X-rayed) self-pollinated. Turkey Heart is in the incompatibility group V S 3.5. The seedling produced 12 fruits from 295 self-pollinated flowers (4 per cent.) : this is a low set but is within the normal range of compatibility. When crossed as a male on to the parent no fruits were produced from I2 I flowers, but in the reciprocal cross I I fruits were produced from 65 flowers ( 17 per cent.).

Another seedling of this type 12/45, obtained from Emperor Francis $\times$ Bigarreau Napoleon $\mathrm{X}$-rayed, was tested in greater detail. Self-pollinating a total of 402 flowers during four consecutive years has given 25 fruits ( 6 per cent.), I 2 of these dropped from the tree prematurely probably due to embryo abortion. The total result, however, shows that the tree is self-compatible. Crossing as a male on to the parent gave two fruits from 265 flowers ( 0.8 per cent.), a result which can be classified as incompatible. In the reciprocal cross 20 flowers gave 16 fruits ( 80 per cent.).

The data suggest that the constitution of the seedlings is either $\mathrm{S}_{3}{ }^{0} \cdot 4$ or $\mathrm{S}_{3} \cdot 4^{0}$, in which the 0 suffix denotes a change in the stylar 
activity of the $\mathbf{S}$ gene. The incompatibility of the seedling pollen with the parental genotype shows that the pollen part of the $\mathbf{S}$ gene is unaltered. If this is so the self-fertility can only be due to a mutation in the stylar part of the gene. This possibility is strengthened by the compatibility of the cross between the seedling and parent with the seedling as female. But without further information this could also be due to homozygosity of the seedling. This possibility was excluded by the evidence from the following crosses :

\begin{tabular}{|l|c|c|c|}
\hline & Flowers & Fruits & Per cent. \\
\hline Governor Wood $\left(\mathrm{S}_{3} .6\right) \times 12 / 45\left(\mathrm{~S}_{3^{0}} \cdot 4\right)$ & 82 & 22 & 27 \\
G. de Hedelfingen $\left(\mathbf{S}_{4.5}\right) \times 12 / 45\left(\mathrm{~S}_{3^{0}} \cdot 4\right)$ & $25^{2}$ & 112 & 44 \\
\hline
\end{tabular}

Thus $12 / 45$ cannot be a homozygote $S_{3.3}$ or $S_{4.4}$ since the pollen is compatible on both $\mathbf{S}_{3} .6$ and $\mathbf{S}_{4.5}$ styles. table 2.

The results of all tests with seedling $12 / 45$ are summarised in

TABLE 2

Results of test pollinations with seedling $12 / 45\left(\mathrm{~S}_{3}{ }^{0} .4\right)$

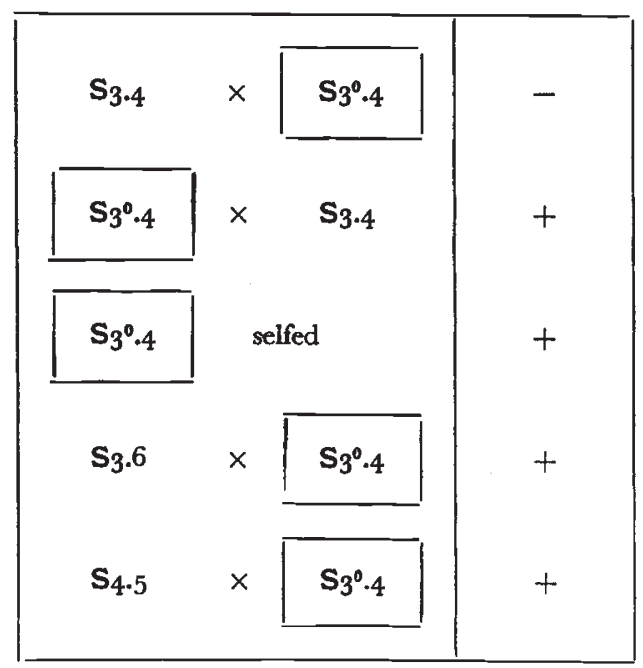

The only interpretation which fits these results is that the mutated allele has a changed activity in the style but the original activity in the pollen. The mode of its origin will be discussed later.

\section{Types 4 and 5}

These are types which have been found frequently in EEnothera and are fairly well understood. They are due to a mutation of the pollen part which has later reverted to normal. An example of type 4 is found in seedling $6 \mathrm{I} / 46$ obtained from Hooker's Black $\times \mathrm{G}$. de Hedelfingen (X-rayed). This seedling when selfed produced no 
fruits from 228 flowers, when crossed as male on to the parent 166 flowers gave no fruits and the reciprocal cross gave no fruits from I56 flowers. This is clearly a heterozygote like the parent which is the result of a revertible mutation.

Type 5 in which the seedling is self-incompatible, is incompatible as a male but compatible as a female, has two possible interpretations but the most likely is a revertible mutant as in Type 4 but a homozygote.

\section{Type 6}

This type is found in seedling $10 / 45$ which was obtained from Late Black Bigarreau $\mathrm{S}_{3.5} \times$ Turkey Heart (X-rayed). It produced no

\section{TABLE 3}

The numbers of different types of mutations obtained with and without $X$-rays; owing to a possible loss of identity of one tree it was impossible to classify completely the eight self-sterile seedlings from spontaneous mutation

\begin{tabular}{|c|c|c|c|c|}
\hline & \multicolumn{2}{|c|}{ Self-fertile } & \multicolumn{2}{|c|}{ Self-sterile } \\
\hline & Types 1 and 2 & Type 3 & Types 4 and 5 & Type 6 \\
\hline & $\begin{array}{l}\text { Permanent } \\
\text { "pollen" loss }\end{array}$ & $\begin{array}{l}\text { Permanent } \\
\text { "style" loss } \\
\text { revertible } \\
\text { "pollen" }\end{array}$ & $\begin{array}{l}\text { Revertible } \\
\text { "pollen" }\end{array}$ & $\underset{?}{\text { Contamination }}$ \\
\hline X-rays . & 3 & 2 & 9 & 10 \\
\hline Spontaneous & I & $\mathbf{I}$ & $\leftarrow$ & $\longrightarrow$ \\
\hline
\end{tabular}

fruits from selfing 64 flowers, when crossed on to its parent 480 flowers gave 100 fruits ( 21 per cent.) and in the reciprocal cross 54 flowers gave 7 fruits ( 13 per cent.). Thus it is self-incompatible and compatible both ways with the parent. This can only mean either that it was the result of a contamination from a pollen grain from a tree in another incompatibility group or that a new active allele had arisen by mutation.

Seedling 10/45 was tested on a limited scale with some of the possible sources of contamination and it was found to be $S_{3.4}$ due to a contamination from $\mathrm{S}_{3.4}$ trees which were in the greenhouse at the same time.

With other seedlings of this type it has not been possible to make the tests to exclude contamination as the cause.

\section{FREQUENCIES OF DIFFERENT TYPES OF MUTANTS}

Fifty-two seedlings derived from self-pollination, both with and without X-ray treatment, have been analysed either completely or in part. The general policy after making the tests of self-fertility was 
to concentrate on the more interesting types: thus many of the seedlings have not been completely classified. Some seedlings showed a low degree of self-fertility or compatibility with the parent, these types are presumably due to mutations similar to those giving complete self-fertility but in which the activity is reduced but not lost. Since the analysis of such types would entail much work and time it was not done.

Table 3 gives the frequencies of the different types which have been completely analysed. From this we can see that the revertible mutations which finally retain the original character of self-sterility are more common than permanent loss mutations which give selffertility. Furthermore the same range of types, permanent loss and revertible, occur both spontaneously and after X-rays. This is in keeping with the data on CEnothera organensis (Lewis, I95I).

The X-ray treatments were given to the pollen-mother-cells at different stages of meiosis. The stage is not synchronised in all the buds receiving treatment, and the number of mutations tested is small which makes a classification of the mutations on the stage of irradiation of doubtful significance. It is suggestive, however, at least as a pointer for future work that the three permanent loss X-ray mutations were from resting stage treatments, while among the revertible mutations, 6 were from resting stage, four from prophase and four from metaphase treatments. If permanent mutations to give self-fertility are required it would appear necessary to include resting stage treatments.

\section{DISCUSSION}

All but one of the different types of mutations found in Prunus are similar to those found in CEnothera organensis, and they confirm that the $\mathbf{S}$ gene is a complex of at least two parts. The new type of mutation in Prunus further confirms this interpretation because it is one which has affected the "stylar part" of the gene. This mutation (type 3) has the pollen activity of the $\mathbf{S}$ gene unchanged but has lost its stylar activity. The first sieving test for the mutant allele does not select any "stylar" mutations : it selects only pollen mutants. The chance of obtaining a "stylar" mutation which is independent of a "pollen" mutation is an extremely remote possibility. If, however, a change in the "stylar" part of the gene accompanies a change in the pollen part then the sieve for pollen mutants would at the same time select "stylar" mutants.

In previous publications on Enothera, evidence was presented for the induction by X-rays of revertible mutations of the "pollen" part. Such mutations are of a temporary nature lasting long enough to affect the pollen grain carrying them but reverting before the pollen-mother-cells are formed in the next generation. The type 3 mutants in Prunus are important in the interpretation of the revertible mutations because they imply that simultaneous mutations were 
induced in both pollen and stylar parts of the gene : the pollen part reverted to normal and the stylar part remained permanently changed. The probable cytological basis for X-ray induced revertible mutation has been pointed out by Lewis and Crowe (r953) and by La Cour and Rutishauser (1953).

Data on the most baffling problem, that of the origin of new active alleles, is so far lacking from EEnothera. In Prunus it is impossible to investigate this problem owing to the difficulty of identifying contaminations with certainty.

\section{SUMMARY}

I. X-ray induced and spontaneous mutations of the $\mathbf{S}$ complex in the sweet cherry, Prunus avium, are of three types : (i) permanent loss or change of the pollen activity, (ii) revertible mutation affecting the pollen activity, and (iii) a new type, a permanent loss of the stylar activity.

2. The same range of mutant types are obtained by spontaneous mutation as are induced by $\mathrm{X}$-rays.

3. Permanent loss of either "stylar" or "pollen activity" causes self-fertility. Seedlings which have received only a reverted mutant $\mathbf{S}$ allele are self-sterile like their parent.

4. All the classes of mutations found in CEnothera have also been found in Prunus. In addition the new mutation in Prunus of the " stylar part" has shown that the two components of the S complex (i) can mutate either independently or synchronously and (ii) can revert to normal independently.

\section{REFERENCES}

CRANE, M. B., AND BROWN, A. G. 1937. Incompatibility and sterility in the sweet cherry Prunus avium L. 7. Pomol., 15, 86-116.

IA COUR, L. F., AND RUTishauser, A. 1953. Chromosome breakage experiments with endosperm : Sub-chromatid breakage. Nature, I7I, 501 .

LEWIS, D. 1948. Structure of the incompatibility gene I. Heredity, 2, 219-236.

LEWIS, D. 1949. Structure of the incompatibility gene II. Heredity, 3, 339-355.

LEWIS, D. 1951. Structure of the incompatibility gene III. Heredity, 5, 399-414.

LEWIS, D., AND CROWE, L. K. 1953. Theory of revertible mutation. Nature, I7I, 501. 